\title{
The Texture of Time
}

\author{
HANNAH EAGLESON
}

University of Delaware

Des ciseaux et de la colle. Des ailes sur une page. La grandeur des caractères. Ces matériaux ont tous eu leur importance lorsque les lecteurs du début du XVII siècle ont tenté de comprendre leur théologie du temps à travers les pages de leurs livres. Cet article montre que la poésie de George Herbert revêt une profonde association entre les idées concernant le texte et celles relevant de l' histoire théologique, association qui était familière pour les lecteurs d'almanachs et d'harmonies bibliques. Les poèmes d'Herbert impliquent que l'individu puisse donner une signification à sa propre vie, dans le cadre d'une histoire théologique linéaire et cohérente basée sur la création, la chute, la rédemption et la résurrection des morts. Puisque cette histoire linéaire se basait sur les Écritures et sur son interprétation dans l'Angleterre du XVII siècle, la démarche consistant à donner une signification à une vie individuelle dans le cadre de cette histoire théologique était expérimentée à travers le texte, considéré à la fois comme un contenu intellectuel et comme une forme matérielle. The Temple révèle également des tensions entre l'exploration d'Herbert dans le temps de chaque jour apparemment chaotique et sa foi dans la cohérence de l'histoire théologique linéaire. Ses efforts pour réduire ces tensions le conduit à utiliser des métaphores impliquant la matérialité du texte, renforçant ainsi les liens entre la théologie du temps et la matérialité du texte dans son œuvre, ainsi que dans l'expérience de ses lecteurs contemporains.

$\mathrm{W}$ ings on a page. Larks and song. The Easter story. Shape poems such as Herbert's "Easter Wings" can seem quaint relics of a minor Renaissance interest in emblematic verse, useful for temporarily surprising bored undergraduates, but providing little evidence of wider seventeenth-century concerns to twenty-firstcentury readers. ${ }^{1}$ I would argue, however, that the "Easter Wings" poems reveal a deep association between expectations about texts and expectations about history, an association that would have been familiar to many early seventeenth-century readers ${ }^{2}$ from other sources and that Herbert uses in his poetry as a way of understanding the individual self in light of history. More specifically, the poems imply that the individual can make sense of his or her individual life in light of the outline of theological history (creation, fall, redemption, and final resurrection); and this 
process of seeking meaning takes place through texts, considered both in terms of intellectual content and material form.

Harold Toliver has drawn attention to the importance of theological history as a narrative in Herbert's work, and to the relationship of the individual to that history. ${ }^{3}$ He observes that the "Easter Wings" poems, read together, imply a deep association between theological history and the individual life, and a hope for a satisfying end for the individual human in both. ${ }^{4}$ One of them moves through the major events of Christian history in outline and then abruptly inserts the individual into them. It begins with creation, moves on to the fall and subsequent decay, and then, just as it is evoking redemption and specifically the resurrection, inserts a personal voice that hopes to rise based on what has happened. The other offers a parallel shape and story for the individual. It begins with a life presumably sharing in humanity's fallen state (since it "in sorrow did beginne"), chronicles the further decay of sin and suffering, and then asks for a parallel rising motion related to God's work in the individual. Randall McLeod observes that the orientation on the page of the poems in the 1633 edition allows either one to be read first, and perhaps allows the reader to see the two as a right and left wing, working together, which deepens the association between individual and historical narrative. 5 Time takes a narrative shape, whether as theological history or the individual effort to shape the events of a life in a parallel motion to that theological history.

As critics have also commented, the poems associate the narrative of history and the individual life with the details of textual arrangement on the page. One poem begins by describing creation in the long line that begins the poem, and then gradually pares the length of the lines as the poem narrates the fall and the further decay that results from it, until the lines reach their shortest point at "Most poore." The narrative of the fall and its resulting decay is paralleled exactly by the dwindling shape of the poem, so that the poem's theological point and its textual arrangement reinforce each other. ${ }^{6}$ At the poem's thinnest point, an identification between God and humans is introduced in a parallel to "Most poore" ("With thee"), and in the next line the resurrection is explicitly invoked as an instance not only of Christ's rising from the dead but of the narrator's rising from the general decay of the fall. As the effects of redemption are anticipated, the poem broadens out again until the last line achieves the same length as the first. The history of redemption is thus evoked both through the language of theological history and through the reader's visual experience of the page. The other poem uses the same visual pattern for a parallel experience of dwindling and rising in the time span of the individual life. 
Text, history, and a particular hope for human experience are linked in both poems, and I will argue that this linking extends beyond "Easter Wings." In light of a long critical tradition discussing Herbert's work in its theological context, and a growing body of critical literature emphasizing the cultural and material circumstances of Herbert's life and work, ${ }^{7}$ Herbert's own poetic meditation on the experience of time and the experience of texts is worth revisiting. Herbert criticism has been long noted for its interaction with theological discourse, and many commentators on Herbert's theology have also explored to some degree Herbert's material contexts. Among the most influential books of this type are Barbara Lewalski's Protestant Poetics and the Seventeenth-Century Religious Lyric, which offers a catalogue of Protestant theological background illuminating Herbert's work, including reflection on the emblematic tradition; Stanley Fish's The Living Temple, which explores Herbert's work in light of early modern catechisms; and Richard Strier's Love Known, which emphasizes the importance in Herbert's work of the Protestant doctrine of justification by faith. ${ }^{8}$

Recent Herbert criticism has taken part in a wider critical turn toward material contexts, ${ }^{9}$ including those of book history and the bodily and intellectual experience of early seventeenth-century readers. The publication history of The Temple and critical debate over it is well summarized in Helen Wilcox's 2007 edition, The English Poems of George Herbert. ${ }^{10}$ Randall McLeod, writing under the name Random Cloud in order to emphasize the unpredictability of textual transformations, has catalogued in the article "FIAT $f$ LUX" many editions of The Temple and the transformations that "Easter Wings" has undergone. His essay emphasizes the possible chaos of print, but also the ways in which the meaning of Herbert's text and the shapes on the page are related. ${ }^{11}$ Kathleen Lynch has discussed the implications of bookbinding for the reception history and social significance of The Temple in "Devotion Bound: A Social History of The Temple." ${ }^{2}$ Ramie Targoff has written of the textuality as well as the theological significance of The Temple, making an argument for both intellectual and material resemblances between the first edition of The Temple and the Book of Common Prayer. ${ }^{13}$

As criticism seeks further to integrate understandings of the theology and the textuality of Herbert's poetry, I want to revisit some of The Temple's own poetic explorations of the relationship between theological history and textuality. In doing so, I recognize that The Temple is attentive in its metaphors to the experience of readers, an experience that constructs theology as both spiritual and material, concerned with both the words of a text and the presentation of those words on the page. In what follows, I begin by defining some key terms. Next, I establish further 
material and intellectual contexts for considering the relationship between history and text to which Herbert or his early readers could have had access. Finally, I revisit Herbert's poetry in order to explore ways in which the poems deal with tensions inherent in Herbert's expectations about time, and the degree to which he relies on textual metaphors in trying to resolve these tensions.

\section{Text, history, and expectations of coherence}

We have, then, two key terms, "text" and "history," to which I will add the word "coherence" as a short description of the expectation Herbert holds about both human history and the individual's end in light of human history. One meaning of "text" I am using here concerns materials containing words presumed by a reader to have the possibility of making meaning in some way. Texts in this sense can of course be much more than the sum of their words, as D. F. McKenzie has convincingly argued in Bibliography and the Sociology of Texts. The use of the materials in which words are expressed and the visual arrangement of the texts (as the shape poetry amply demonstrates) can be a part of the text's meaning, integrated with the words, striving against the words, or even sometimes assuming more importance. ${ }^{14}$

The second resonance of the word "text" that I am considering here is based on the root meaning of the word as something woven, ${ }^{15}$ including in that idea the sense of many individual things (threads, pages, ideas) being made into a whole that fits together harmoniously. Herbert's poetry implies that the resources of textual arrangement in the first sense, including the possibility of making meaning through the resources of both language and material arrangement, are able to produce or demonstrate the coherence of many apparently disparate elements, thus producing a whole.

It is probably easiest to consider the ideas of time and coherence together, in light of my definitions of text. Specifically, I am arguing that The Temple uses the resources of the first kind of text in order to attempt to demonstrate that history possesses the kind of coherence described in the second meaning of text, and that in light of history the experience of time in the individual life can also be read as coherent. In order to explain what I mean by "coherence" in history and the individual life, I turn to a theoretical framework derived from Paul Ricoeur's Time and Narrative. Ricoeur suggests that one human resource for dealing with the apparently discordant experience of time is the making of narratives about time that seem to supply unity to human experience. Ricoeur's arguments offer an interpretive lens for understanding a wider seventeenth-century Protestant investment in a unified 
biblical text, as well as the more specific explorations of that investment found in Herbert's poetry. It is not my intention here to argue for a transhistorical human desire for coherence, but to suggest that Ricoeur's more general argument happens to summarize well a strain of thought within early seventeenth-century English reflection.

Meditating on Augustine's difficulties with time in Book 11 of Confessions, Ricoeur suggests that humans comprehend the apparently discordant lived experience of time through the ability to make plots, to find a way of seeing apparently fragmentary events as part of one unified narrative in which no event is extraneous and no necessary event is missing:

\begin{abstract}
Augustine groaned under the existential burden of discordance. Aristotle discerns in the poetic act par excellence-the composing of the tragic poem - the triumph of concordance over discordance. It goes without saying that it is I, the reader of Augustine and Aristotle, who establishes this relationship between a lived experience where discordance rends concordance and an eminently verbal experience where concordance mends discordance. ${ }^{16}$
\end{abstract}

What the verbal articulation of an Aristotelian plot does, ${ }^{17}$ in Ricoeur's thought, is to make sense of apparently divergent (and possibly painful) elements of experience. Humans strive through narrative to link heterogeneous elements into an understandable whole: "Plot, in effect, 'comprehends' in one intelligible whole, circumstances, goals, interactions, and unintended results. ${ }^{\text {18 }}$ When the audience knows the whole of an Aristotelian plot, nothing in the drama or epic seems wasted or unnecessary. Knowing all the events of the plot including the ending allows the reader to see that each part fits together into a whole, however disparate the individual actions might have appeared before the narrative had been experienced in its entirety. To add or remove a single incident would damage the story. In Ricoeur's model, if an individual is able to find a plot that seems to link the apparently heterogeneous experiences of individual life and/or history into a coherent narrative, a sense of psychological concordance results. Thus it is the ability to see history or the individual life as having narrative coherence that allows a sense of individual coherence.

Ricoeur argues elsewhere that many people have seen Scripture as a source of narrative and individual coherence on the scale of world history:

In this sense, the Bible is the grandiose plot of the history of the world, and each literary plot is a sort of miniature version of the great plot that joins Apocalypse and Genesis. In this way, the eschatological myth and the Aristotelian muthos are joined together in their way of tying a beginning to an ending and proposing to the imagination the triumph of concordance over discordance. ${ }^{19}$ 
Of course, this understanding of Scripture as unifying plot is not universally held, but I am arguing that a similar understanding was held by many early seventeenthcentury English readers. I would argue that Herbert and others were deeply invested in experiencing Scripture as a narrative or plot because they found in that narrative a hope that history would eventually supply "the triumph of concordance over discordance." Ricoeur emphasizes the necessity of knowing the end of a story in order to judge whether it has Aristotelian coherence. ${ }^{20}$ In light of the ending, the reader can look back and see whether every element of the story is necessary and whether any of it is extraneous. For many seventeenth-century readers, an investment in Scripture as a narrative provided an expected end to the story and therefore a hope that everything would eventually be seen to cohere around that end. Early modern theology implies that the end of history (which I am using like the Greek telos to mean both "temporal end" and "purpose") is harmony between God and humans. The achievement of that harmony falls into a pattern resembling what critics might now call a plot structure. At creation, harmony exists between God and humans, but it is lost as history enters conflict at the fall. Redemption, functioning as the climax of the narrative, introduces the possibility of restored harmony, but the final achievement of that end waits until the end of time with judgment and resurrection.

We might call this expectation of restored harmony an expectation of eschatological coherence, which is in turn based on an expectation of narrative coherence in history. This expectation includes the hope that one day all of history will be seen to matter, that none of it will be extraneous and nothing necessary will be missing, and that all things will come to their proper telos (in the sense of both temporal end and purpose). I want to acknowledge at this point that there are hermeneutic and experiential tensions in this expectation of historical coherence. There has been wide debate in the last few centuries over whether Scripture constitutes a whole or a set of heterogeneous parts, and early seventeenth-century writers, though generally coming down on the side of the whole, do recognize that not everyone shares their opinion, judging by the frequency of early modern efforts to demonstrate that Scripture is a whole. However, the hermeneutic discussion could occupy hundreds of books (and has done so). What I am interested in here is not judging the success or failure of early modern arguments for coherence, but considering the expectations and the tensions inherent in seeking to live with a textually inflected mode of belief in coherence. I will return to the experiential tensions later in a discussion of Herbert's poems. First, though, I would like to survey several categories of evidence among other works produced in the early seventeenth century that (taken 
together) locate an expectation of historical coherence in an effort to demonstrate textual coherence.

\section{Expectations of narrative coherence in biblical history}

Evidence suggests that many English Protestants were committed to a narrative mode of reading history that was based on an investment in the Bible as a unified text. Alison Chapman argues that the English Reformation was more oriented towards linear readings of time, whereas medieval Catholicism had emphasized the cyclical repetitions of the church calendar. ${ }^{21}$ Reformation writers such as Foxe emphasized the importance of linear history, because they wanted to construct a chronological narrative in which readers could chart a clear Protestant break with Rome. Cranmer's restructuring of the liturgical calendar kept aspects of the cyclical experience of time inherent in the pre-Reformation liturgy, but it added linear elements as well, particularly in the Scripture readings. Scripture reading had previously been chiefly cyclical, with passages relating to saints' days or festivals such as Easter aligned with the calendar regardless of the order of passages in the Bible. Cranmer's plan kept some of the liturgical cycling for holy days (readings about Christ's death and resurrection still dominated near Easter, for instance), but also instituted a reading of most of Scripture in linear fashion, reading consecutively rather than skipping around. ${ }^{22}$

Along with investment in linear time in polemic and liturgy, Protestants had an interest in linear narrative in their interpretations of Scripture. Hans Frei has argued that the Renaissance and Reformation produced a hermeneutic strategy that emphasized a unified historical narrative in the Bible. ${ }^{23}$ Many early seventeenth-century textual interactions with Scripture portray it not as a collection of heterogeneous works with different historical interests, but as a unified story given by a single author (God), even as it was penned by multiple human authors. This portrayal of Scripture and history as a unified story appears in textual aids to understanding Scripture, such as the apparatus to editions of the Geneva Bible, George Herbert's own advice on Bible reading in The Country Parson, and biblical harmonies. Beyond textual aids to reading the Bible, an expectation that biblical history shapes the rest of history can also be found in the timelines included in many early modern almanacs.

When Patrick Collinson builds a case that many early modern Englishmen and women saw Scripture as "all of a seamless piece, without caesura or conflict,"24 one of his most compelling pieces of evidence is a chart in the Geneva Bible ${ }^{25}$ labeled in the edition I have used: "Howe to take profite in reading of the holy Scriptures." 
The chart recommends attention to the "Coherence of the text, how it hangeth together," and "Agreement that one place of Scripture hath with an other, whereby that which seemeth darke in one is made easie in an other." ${ }^{26}$ The next page is titled "THE SUMME OF THE whole Scripture of the bookes of the olde and new Testament," and it begins a two-page summary of the Bible, presented very much as a plot summary of a single-author novel might later be. References are made to specific books, but these are placed in the margins while the centre of the page is filled by an account of theological history (with wording heavily indebted to the scriptural passages in the margins) focusing on creation, sin, the coming of Christ to redeem, Christ's relevance to the reader's current spiritual state, and Christ's eventual return. ${ }^{27}$ The chart assumes that Scripture coheres around this central outline of significant events.

It is reasonable to object that individual reading practice may not have emphasized textual continuity to the same degree as devotional aids. Peter Stallybrass, for instance, points out in "Books and Scrolls" that many early modern readers of the Bible read discontinuously, not as though they were reading a modern novel. ${ }^{28}$ Would the experience of skipping around in devotional reading have lessened the reader's sense of textual coherence? I argue that discontinuous reading was a technique consciously employed by early moderns toward the goal of seeing harmony in a text perceived as both single author (God) and multiple author (all the human writers). Reading discontinuously allowed early modern readers to seek out and compare sections of Scripture they felt to have especial coherence with each other, without feeling pressure to insist on an obvious linear transition from, say, Esther to Job.

George Herbert's prose assumes that part of the reader's task is to seek out coherence in the Bible, which involves comparing passages that have thematic similarity, but might not be next to each other on the page. In The Country Parson, Herbert advises readers on how best to approach the Bible:

The third means is a diligent collation of Scripture with Scripture. For all truth being consonant to itself, and all being penned by one and the self-same Spirit, it cannot be but that an industrious and judicious comparing of place with place must be a singular help for the right understanding of the Scriptures. ${ }^{29}$

Herbert's intended readers would have had a textual aid available for such "diligent collation." The interaction of discontinuous reading practices and interpretive strategies aimed at finding coherence took material form in the biblical "harmony," a textual form that had a long history but enjoyed special popularity among both Catholics and Protestants after the Reformation. ${ }^{30}$ Harmonies were books that placed different scriptural accounts of the same events (such as the Gospels) side by side, or 
interwove the different verses, with the goal of weaving the accounts into a seamless whole. As Paul Dyck has argued, the early modern belief in the narrative coherence of Scripture assumed that the unity was latent in the text, waiting to be discovered by the reader, but it also put considerable stress on the reader's responsibility to find that unity. ${ }^{31}$ The harmony provided a material aid to this process.

While most harmonies were not ambitious enough to take on the whole Bible, they did aim to reinforce a relationship between narrative coherence and textual form in the reader's mind. Prefatory materials from some of the harmonies in English ${ }^{32}$ were at pains to emphasize the ways in which textual arrangement of the harmony aided the reader in seeing the historical and narrative coherence of the Bible. The title page of Johan Hiud's 1632 printed harmony emphasizes both narrative and harmonious agreement: The Storie of Stories or the Life of Christ According to the Foure Holy Evangelists: with a Harmonie of them, and a Table of their Chapters and Verses. ${ }^{33}$ In the preface, Hiud describes the coherence made more visible by his work in putting the Gospels together into a "historicall frame":

Briefly I have endeavoured, as fully as conveniently I could, to reduce and to bring all what is written by the foure holy Evangelists, into such an historicall frame, that by a plaine and distinct disposition it might be had as it were in one view and continual coherence of time and order ... ${ }^{34}$

Hiud's work encouraged the reader to pay attention to details of the material text in order to grasp the coherence of the narrative. Hiud explained that he had used larger typography in order to show those parts of the text that gave indications of time, and argued that this would demonstrate the text's coherence:

... those words, which doe shew the time of the severall occurrences, is given a bigger or grosser letter, then to all the rest, that by them as by certaine guides you may goe along to finde out your selfe, and to see at ease without any need of further direction, the dependance and coherence of one matter or particular with the other, together with the continuance of the whole Story. ${ }^{35}$

He argues again later that the reader paying attention to the typography and its significance will easily see the wholeness of the narrative: "For thus doing ye will find the one so point at the other, as the coherence will shew it selfe clearly," he writes. ${ }^{36}$

A similar attitude towards textual attention and narrative coherence is evident in the practice of Little Gidding, the religious community led by Herbert's friend Nicholas Ferrar, which produced its own harmonies ${ }^{37}$ by cutting sections of Bibles up into individual verses, then pasting the verses together on sheets of paper. ${ }^{38}$ These sheets were then put together and bound into harmonies, ${ }^{39}$ or as they were 
called at Little Gidding, concordances. $4^{40}$ The introductory matter of the concordances and the circumstances of their production again associate the recognition of the narrative's coherence with the attention of readers to the material text. As in Hiud's printed work, the titling and introductory material of the Little Gidding concordances emphasize the coherence of Scripture. Dyck notes the significance of titling the books "concordances,"41 a word that carried connotations of general accord as well as citations of parallel passages. ${ }^{42}$ Further, the title page of Little Gidding's Gospel harmony from 1635 emphasizes the unity of the story of Christ and the compatibility of the four Gospels, and appears remarkably comfortable with having radically rearranged the material form of the texts in order to draw attention to that expected unity. ${ }^{43}$ It announces in part:

THE/ACTIONS \& DOCTRINE \& Other PASSAGES touching/Our Lord \& Savior JESUS CHRIST, as they are Related by the/FOURE EVANGELISTS./Reduced unto one Complete Body of HISTORIE, wherein/That which is SEVERALLY Related by them is Digested into ORDER/And that which is JOINTLY Related by all or any two of them/is First expressed in their own Words by way of COMPARISON,/ And secondly brought into one Narration by way of COMPOSITION./ And Thirdly extracted into one clear Context by way of COLLECTION. ${ }^{44}$

The title page is also at pains to assure the reader that the words of the four evangelists are all fully present in the harmony, although the order has been changed. 45

In the case of the Little Gidding concordances, many of the readers were also producers of the books, since they were originally designed for use in the same community that made them. ${ }^{46}$ The painstaking process of designing a harmony for communal reading associated attention to narrative coherence with attention to the material form of the text. The care involved was detailed by John Ferrar, Nicholas's brother. He describes the cutting and pasting process and then adds:
And so artificially they performed this new-found-out way, as it were a new kind of printing, for all that saw the books when they were done took them to be printed the ordinary way, so finely were the verses joined together and with great presses for that purpose pressed down upon the white sheets of paper. ${ }^{47}$

Even making allowances for John's sometimes imperfect memory, ${ }^{48}$ it is clear that the process of demonstrating what the community saw as the inherent coherence of Scripture caused them to give great attention to the material form of the text.

Outside the world of devotional aids, there is some evidence of expectations about the coherence of history based on the coherence of Scripture. Early modern almanacs, a widely popular form in the seventeenth century, ${ }^{49}$ frequently include a chart or timeline of happenings in world history, and the material form of these 
charts often suggests that history is a unified, continuous narrative, beginning with biblical events and running through the present. In 1620, when Herbert was in his late twenties, Daniel Browne. $5^{\circ}$ William Dade ${ }^{51}$ Gabriel Frende, ${ }^{52}$ Jeffery Neve, ${ }^{53}$ Arthur Sofford, ${ }^{54}$ John White, ${ }^{55}$ and John Woodhouse ${ }^{56}$ all included such timelines in their almanacs. The chart from Sofford's almanac provides a fairly typical example. Sofford's timeline is headed "A briefe Computation of time compleat within this present yeare 1620." It begins with the number of years between the creation of the world and the present year and progresses through various biblical, classical, and recent events, weaving them into one table. Thus Noah's flood, the death of Alexander the Great, and the events of Tilbury all appear on the same page, with notations as to how many years have passed between them and 1620 . The visual presentation on the page and the interweaving of these events hints that they are all part of a narrative, in which the readers of the almanac still find themselves, impacted by the past. The pages imply via their layout that all of these events are part of one unified history. ${ }^{57}$ Often the charts date the beginning of the world to a specific year, and sometimes to a specific month, increasing the sense that ancient time and present time are part of a complete continuum. Sofford's 1632 almanac dates the beginning of the world to October, "as is supposed." 58

Some almanacs also present Christ's life as a turning point in this ongoing narrative of history. Browne's almanac divides the chart into ages of history, with the last division at the birth of Christ, emphasizing the pivotal role of the incarnation in the unfolding of history. ${ }^{59}$ In 1632 , the year before Herbert's death, Sofford's almanac breaks history into segments based on biblical events, using boxes printed next to the text of the timeline to delineate different periods. The first box reads "From the Creation to the Promise, are 2083 yeares recorded, Gen. 5 and 11." The boxes continue with the years between the promise to Abraham and the Israelite departure from Egypt, the years between the departure from Egypt and the building of Solomon's temple (which years also included the fall of Troy, according to the chart), and so forth. The chart portrays Christ's death and resurrection as a pivotal point of history. The description of the event in the chart reads: "HEE sealed up mans Redemption, by his Death and Passion, Dan. 9, 24, 25, 26, 27" and the boxes for biblical time in the rest of the chart are described under "Christ." ${ }^{\text {. }}$ The textual form of the almanac portrays an ongoing linear story of time, with a climactic change at redemption. 


\section{The Temple}

In light of the materials I have surveyed implying an early modern investment in the coherence of theological history, I would argue that the poetry of The Temple strongly emphasizes an expectation that a proper understanding of the coherent text of Scripture will produce coherence in the individual life. Poems such as "The Pulley" and "The Elixir" imply that individual human wholeness comes from the experience of having all one's faculties and desires centred on God and therefore satisfied, and other poems tie the expectation of harmony with God to the outline of God's work in history, recorded in the text of Scripture. However, this expectation of historical and individual coherence derived from a text also produces tensions in experience, which often seems fragmentary and painful, and Herbert's efforts to resolve those tensions often turn to textual metaphor as well. In these textual metaphors, Herbert is attentive both to the content of texts and the bodily experience of readers.

“The H. Scriptures II" serves as an example of these expectations of textual and therefore individual concord, beginning with Herbert's ${ }^{61}$ confidence in the text's inherent coherence with itself. Many critics have noted the affinities between the style of reading encouraged by the Little Gidding Concordances and that recommended in "The H. Scriptures II." ${ }^{2}$ It is worth revisiting the poem here in order to link its expectations with those of several other poems that deal with the relationship between text and coherence. Herbert begins by comparing the verses of Scripture to constellations, implying that they are naturally placed in certain patterns (described as a story) and that it is his desire to see these patterns, which are not always immediately obvious:

\section{Oh that I knew how all thy lights combine, And the configurations of their glorie! \\ Seeing not onely how each verse doth shine, But all the constellations of the storie. $(1-4)^{63}$}

As stars can be read by the human viewer as constellations, so the individual verses of Scripture together make up a coherent narrative; but as the constellations may remain unseen without attention, so finding the coherence in Scripture requires attention to "the storie," which as Wilcox notes often means in Herbert the narrative of salvation. ${ }^{64}$

While the image of the constellations might suggest that human agency is necessary in order to see the configurations, the second stanza implies that the unity of the text has its own agency, ${ }^{65}$ which eventually produces change in the reader. 
Herbert uses the language of material texts to emphasize that the agency belongs to the words and the pages of Scripture. The human reader is present, but more as the one acted upon than as the actor:

\author{
This verse marks that, and both do make a motion \\ Unto a third, that ten leaves off doth lie: \\ Then as dispersed herbs do watch a potion, \\ These three make up some Christians destinie: $(5-8)^{66}$
}

Separate herbs scattered in water work together to become one healthful potion, ${ }^{67}$ and apparently separate passages scattered in the human life brew health for the reader. The pun on leaves, in which different leaves of the Bible are likened to scattered leaves of herbs, plays with the idea of the reader's experience of turning pages as well as with the theological point that different sections of the text cohere.

The text, considered as material and intellectual, brings the reader into concord with itself, both in the experience of everyday life and in the hope of eschatological wholeness. The reader becomes marginal commentary to the text: "Such are thy secrets, which my life makes good,/And comments on thee" (9-10). ${ }^{68}$ In the final couplet, the initial image of constellations returns and the navigational power of Scripture for human life is highlighted: "Starres are poore books, \& oftentimes do misse:/This book of starres lights to eternall blisse" (13-14). ${ }^{69}$

The vision of eschatological wholeness is thus founded on the agency of a coherent Scriptural text in Herbert's poetry. The poem "Judgement" relates this confidence in Scriptural text to bring concord to the reader more directly to the narrative of theological history.70 "Judgement" has a particular narrative significance for readers due to its ordering in The Temple. The last five poems in the book deal explicitly with eschatology. The titles themselves tell a compressed narrative of the last things, connoting the temporal end of individual and communal life ("Death" and "Dooms-day"), showing the final judgment ushered in by that temporal end ("Judgement"), and then proceeding to the hoped-for result of that judgment ("Heaven" and "Love [3]").71 The poem "Judgement" serves as the fulcrum of this narrative in brief, making the transition from the topics connoting divine judgment ${ }^{72}$ and the risk of God's possible refusal to reconcile with the individual sinner to the topics connoting human harmony with God. The poem thus works in the structure of The Temple as a decisive moment, the textual locus in which the human subject of the poetry experiences either final reconciliation with God or final rejection by Him. This is the denouement of history, both individual and communal, and Herbert chooses profoundly textual terms in which to describe it. 
The poem introduces fear of divine judgment (brought about by the original conflict of the fall) through the commonplace textual metaphor of the individual conscience as a book. The tradition that each individual's actions are written in a book (sometimes identified with the individual's heart) that will be laid open to God at the final judgment has a long history. Eric Jager's The Book of the Heart attests to the widespread cultural resonance of the metaphor in early Protestant England, giving "Judgement" as one example. ${ }^{73}$

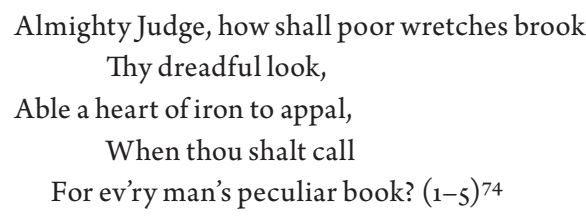

The next stanza explicitly mentions sin, the source of the conflict between God and man, as well as one strategy for dealing with it at the final judgment. The poet hears "That some will turn thee to some leaves therein/So void of sin,/That they in merit shall excel" (8-10). ${ }^{75}$ While Herbert does not elaborate here, early modern theological reflection tended to emphasize the impossibility of hiding anything on the last day. Richard Carpenter's The Conscionable Christian (1623) describes the conscience as a scribe or notary in the closet of the human heart, which "records and keeps a Catalogue or Diary of all our doings, of the time when, place where, the manner how they were performed, and that so clear and evident, that go where we will, do what we can, the characters of them cannot be cancelled or razed." ${ }^{6} \mathrm{In}$ light of passages like this, Herbert's early readers would probably have greeted the dodge suggested in stanza two with skepticism.

Herbert's own strategy for dealing with the conflict performs a textual swap, substituting the text of the New Testament for the text of the individual's life:

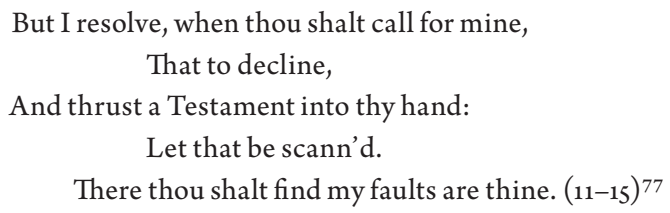

The peripeteia at the end of the poem relies upon the double meaning of "Testament," which connotes both the book of the New Testament and a legal agreement. ${ }^{78}$ As Jager has shown, an early modern Protestant would have expected to stand before God with the book of the individual life laid open, exposing the narrative of all of his or her actions to judgment. The human hope of being declared innocent in Herbert's poem rests on the irony that the judge has placed himself in the same position as 
the judged. God stands with the book of each human's life on earth open, able to judge. But in Herbert's view, God has also written His own book accounting for His actions on earth in Christ, and it lies open to the human reader. The poet can point God to the text of the New Testament as evidence that God has already claimed (and suffered for) the individual's sins as His own in redemption. The narrator of the poem has another textual way of insisting on mercy at the judgment, because the "Testament" in this case is not only a recorded story, but a recorded legal commitment made by God. "Testament" and "covenant" were partially interchangeable in early modern England, so that the word implied binding legal commitments made by God. ${ }^{79}$ Here the "Testament" is both the theological-historical account describing Christ's substitution of Himself for sinners and a legal commitment by God to honor that substitution. God's books - both accounts of actions and accounts of promises-lie open to the human, who can use them to insist on mercy at the judgment. It is the textual account that serves as the binding commitment of God to restore full harmony between himself and the individual, as well as the story of how He brings about the possibility of harmony.

Herbert's poetry assumes that the coherence of theological narrative will bring about individual eschatological coherence, and both beliefs are mediated through poetic explorations of the reader's intertwined bodily and intellectual experience of texts. However, Herbert's poetry also suggests that this expectation of wholeness was capable of producing profound tension in lived experience, since early moderns believed in a coherent narrative of history but recorded experiences of fragmentation in their everyday experience of time. If some early moderns saw history as a narrative, they lived at an awkward place in the plot. Living more than a thousand years after what might be called the climax of the story in Christ's death and resurrection, and at an indefinite distance from the end, they felt the tension of living in what we might call the "falling action." ${ }^{80}$ In many poems Herbert laments the absence of the individual sense of wholeness that he seeks (wholeness meaning a sense of harmony brought about by the centring of the whole individual on God), and these laments are often tied to the inability to see the theological narrative bringing about any sense of coherence in the narrative of his individual life. Indeed, the individual life in The Temple often appears painfully fragmented, as the presence of five poems titled "Affliction" might imply. ${ }^{81}$ In "Home," Herbert expresses the tension between expectations of eschatological wholeness and a painful experience of fragmentation in time in textual terms, while in "Jesu" he uses textual imagery to try to deal with similar tensions within the individual heart. 
In "Home," Herbert expects that his theological narrative will transform not only his eschatological trajectory but also his everyday experience. He expresses an anguished sense of distance from the crucial points of his theological narrative, and therefore a sense of fragmented experience that does not appear to partake in the wholeness he expects. In "Home," this distance affects not only his emotional and spiritual states, but also the text of his poetry. The poem begins with a lament that the poet is far from the telos of his life, and a fervent request that God would either make His presence obvious in the here and now or bring about the poet's individual end:

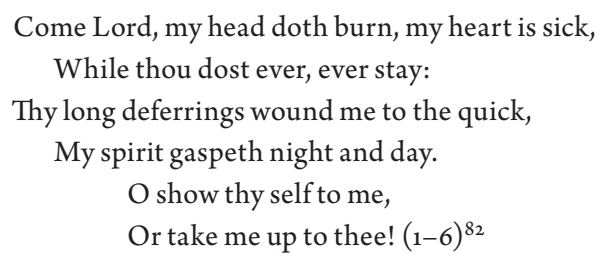

The final couplet is repeated in each successive stanza, intensifying the poem's sense of urgency. It was an urgency other early modern readers may well have felt, given that a number of print and manuscript sources from the seventeenth century allude to "Home." 83

The first stanza, then, emphasizes the sense of fragmentation brought about by the poet's distance from the end and by God's apparent present distance from the poet. Besides expectation of the end, one of the other narrative resources the poet has for expecting a sense of harmony with God is of course the climax of the story in the narrative of redemption, a narrative that is expected to produce confident hope of harmony with God. Yet in "Home," the narrative of redemption induces greater frustration in the poet. If God gave so much in order to make humans whole, why do they still suffer fragmentation in time? The second stanza asks how God can delay in offering the poet a sense of His presence, given His readiness to die for humans:

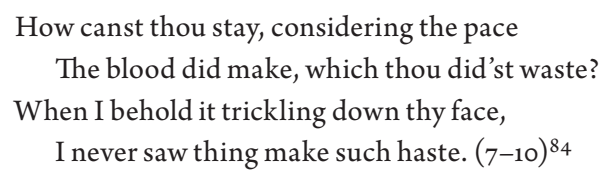

In picturing Christ's blood on the cross in rapid motion, the poet points to God's apparent readiness to help humans; but he also points to his own puzzlement at God's apparent refusal to give him a sense of wholeness now. 
After two stanzas detailing further the action of redemption, the poet explicitly questions how God can still seem distant, given His previous work in history on behalf of the narrator. Herbert begins with an intense repetitive cry insisting on God's previous aid: "He did, he came: O my Redeemer dear,/After all this canst thou be strange?" $(25-26)^{85}$ God seems to deny His attention and therefore the sense of wholeness and peace that the poet expects from it. The sense of distance experienced by the speaker appears incongruous with his theological narrative. The writer eventually falls back on theological assertion of a belief he holds but does not seem to feel: "As if thy love could fail or change" (28). ${ }^{86}$

In the last stanza, the narrator describes how his unfulfilled longing for wholeness causes the disruption not only of his individual and theological narratives, but even of the text of his poetry:

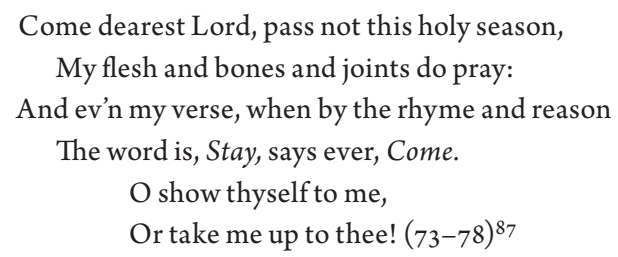

The replacement of the natural rhyme word "Stay" with "Come," is even more striking because the poem uses either the word "stay" or a rhyme for it as part of the rhyme scheme in five different stanzas $(1,6,8,10$, and 13$) .{ }^{88}$ Nowhere do any of the line ends contain a rhyme for "come," so the syllable is completely out of the poem's rhyme pattern, suggesting the discordance of the poet's experience but also perhaps the intensity of his longing. The typography of the 1633 edition also emphasizes the intensity of the desire, since the italic type highlights the contrasting words "Stay," and "Come." 89 As Rosalie Colie has observed, "Come" does visually rhyme with the title "Home," evoking the human's desired end in heaven. It thus highlights a coherence external to the poem itself, expected but not felt within the lines..$^{\circ \circ}$

The poem "Jesu" explores this tension between expected wholeness and individual fragmentation, using a metaphor in which the heart contains a sacred text. When the heart is broken by the afflictions of life, so is the text:

JESU is in my heart, his sacred name Is deeply carved there: but th' other week A great affliction broke the little frame, Ev'n all to pieces, which I went to seek: $(1-4)^{91}$

Herbert's effort to resolve the tension of the poem emphasizes the reader's interpretation of the text. As Lewalski points out, the emblem tradition contains 
images of a divine pen writing the name of Jesus on the heart, ${ }^{22}$ but Helen Wilcox states that the idea of "breaking the name into its constituent parts to discern a hidden meaning" is probably original to Herbert. ${ }^{93}$ Thus the imagery of fragmentation and the importance of interpretation in the poem goes beyond the emblematic context with which it interacts. ${ }^{94}$ The process of interpreting the letters of the broken heart, much like the process of creating biblical harmonies, seeks to find harmony in a text that might appear fragmentary to some, and also to provide a sense of both the parts and the whole. In interpreting the apparently fragmented word carved on the broken heart, the speaker discovers another message in the text, consonant with the original one. He also sees how the process of breaking, because it initiates a new effort to interpret the text, returns him to a renewed sense of the whole. As he seeks the broken pieces, he finds them in a way that reveals additional meaning:

And first I found the corner, where was $J$,

After, where $E S$, and next where $U$ was graved.

When I had got these parcels, instantly

I sat me down to spell them, and perceived

That to my broken heart he was I ease you,

And to my whole is JESU. $(5-10)^{95}$

Thus Herbert's efforts to resolve the fragmentation of the individual heart in light of earthly afflictions also take a textual shape, one that implies a coherence in the text but also a need for interpretive work by the reader.

The reader's interpretive work is not necessarily easy or facile for Herbert, but is a hard-won reassertion of expected unity. Stanley Fish argues in light of early modern spelling rules that contemporary readers would have been surprised by the penultimate line of the poem..$^{96}$ The characters "J" and "I" could have still been read as equivalent or as different (a fact on which the poem turns), but Fish argues that early modern readers would have expected a "J" followed by an "E," as in lines 5 and 6 , to be read as the sound now indicated by "J." Thus, readers (and presumably the speaker of the poem) would have been surprised on reaching line 9 and discovering that the letters were read as "I ease you." Fish further argues that the speaker of the poem has failed to see the full significance of the name "Jesu" until he participates in the brokenness that makes the meaning clearer. This brokenness also echoes Christ's own brokenness, which allowed Christ to become "I ease you" to the speaker in the first place. Fish argues that early modern readers, like memorizers of a catechism finally seeing the point of its assertions, would have experienced the complicated deepening of interpretation recorded by the speaker of the poem: "All of this is contained in the name Jesu, a name the reader always knew in one sense, but knows in its fullness 
when he is drawn into the interpretive drama the poem reports." 97 Fish argues that it is not so important whether the reader's heart is whole or broken, but whether the reader recognizes Christ's significance or not. ${ }^{98}$ While in substantial agreement with Fish's reading, I would argue that the restoration of wholeness at the end of the poem is a deeply felt result of careful interpretation for the poem's speaker.

Herbert's efforts to resolve the tensions of a time-bound being with eschatological aspirations also turn to meditation on time through meditation on the annual retelling of the story of redemption in the church calendar, as in the series of poems about the Easter season beginning with "The Sacrifice" and ending with "Easter Wings." Given the deep relationship of text and time in Herbert's interactions with Scripture and history, it is unsurprising that Herbert's meditation on the time of the liturgical year (shaped by the Book of Common Prayer), leads him in a poem in this series, "Good Friday," 99 to profoundly textual metaphors for his desire for wholeness in God. The poem emphasizes the ease with which humans can forget Christ's work and lose its experiential effect in their lives, and asks that the narrative be written on the human heart in order to drive away sin.

As Wilcox observes, the request that the narrative be written on the heart has ties to other texts. One Herbert must have known is the Epistle prescribed for Good Friday, ${ }^{100}$ Hebrews 10:1-25, which discusses Christ's sacrifice and also includes a quotation from Jeremiah 21:33, which reads in the Authorized Version, "after those days, saith the Lord, I will put my laws into their hearts, and in their minds will I write them/and their sins and iniquities will I remember no more." ${ }^{101}$ The biblical text, read liturgically in conjunction with the Book of Common Prayer in the season of Easter, inspires the poetic discussion of writing on the heart, which in turn fits into a long tradition of devotional texts asking that Christ's sufferings be written on or inscribed in the individual heart in order to transform it. ${ }^{102}$

Barbarah Harman's reading of "Good Friday"103 points out that it begins with a human voice skeptical of its own ability to tell the story of Christ's sufferings: "How shall I measure out thy bloud? How shall I count what thee befell,/And each grief tell?" 104 As the stanzas go on, the human voice remains unsure, proposing different ways of telling the story and finding itself inadequate, until the speaker shifts to what Harman calls "not writing Christ's story but rather internalizing it."105 Herbert asks that his experience of time be filled with Christ's grief:

Then let each houre

Of my whole life one griefe devoure;

That thy distresse through all may runne,

And be my sunne. ${ }^{106}$ 
In Harman's reading, it is this shift to attempting to internalize the story that moves the speaker from trying to tell the story himself to asking God to inscribe it on his heart:

\author{
Since blood is fittest, Lord, to write \\ Thy sorrows in, and bloody fight; \\ My heart hath store, write there, where in \\ One box doth lie both ink and sin: $(21-24)^{107}$
}

Blood itself is the best ink in which to record the shedding of Christ's blood, and the poet asks that the story be written in his heart, his own blood used as ink. In this, Herbert's poem is accurately described by Jager's words about a medieval Orison: "Christ, the author of human salvation, thereby becomes the author of the inner book as well, transcribing his wounds from the exemplar of his own body to a copy in the believer's heart and turning the sacred scenes of the Passion into devotional passages of a personal memory book." ${ }^{108}$ Herbert hopes that this rewriting of the narrative will drive the sin from his heart, allowing him to have a fuller sense of wholeness and harmony with God. As Harman puts it, "The new story, written by God on the speaker's heart, would displace the sinful, personal story already lodged therein." 109 The narrator hopes that sin will see the narrative written in blood and vanish:

That when sin spies so many foes, Thy whips, thy nails, thy wounds, thy woes

All come to lodge there, sin may say,

No room for me, and fly away. $(25-28)^{110}$

The end of the poem pleads for God's help, recognizing how easily humans forget the narrative of redemption and lose its effect on their lives. Even this plea takes place in textual terms, however, fearing that sin will blot or burn the writings recording God's story in the heart:

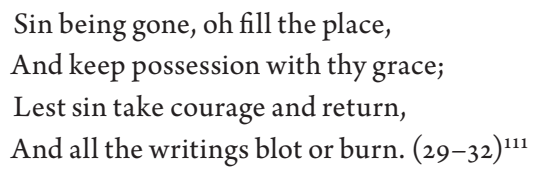

The hope for wholeness in God, experienced in everyday life as well as expected in eschatological time, is thus inextricably intertwined not only with the narrative of redemption but also with textual metaphor for understanding that narrative's effect on the individual. As long as the speaker remains in time, however, there is some ambiguity. There is a hopeful request for a new text that will eventually lead 
to eschatological wholeness, but there is also a recognition of the fragmentation to be feared before history is completed.

Coherence in time and text, then, are frequently identified in textual sources produced near the time in which The Temple was written, and Herbert works with the relationship between the two in his poetry and with the individual import of that relationship. History is seen as a theological narrative experienced through texts in both intellectual and material terms. Tensions in the psychological experience of the self invested in that narrative are mediated through textual approaches to yearly time. The root meaning of "text" as something woven ${ }^{112}$ reflects what early moderns sought from their textual approaches to the concept of time. In weaving material texts together, they sought a weaving of history into a coherent narrative, and a weaving of the self into a coherent whole that fit into that larger narrative. Herbert's poetry was widely read and alluded to in the seventeenth century, both in printed sources and

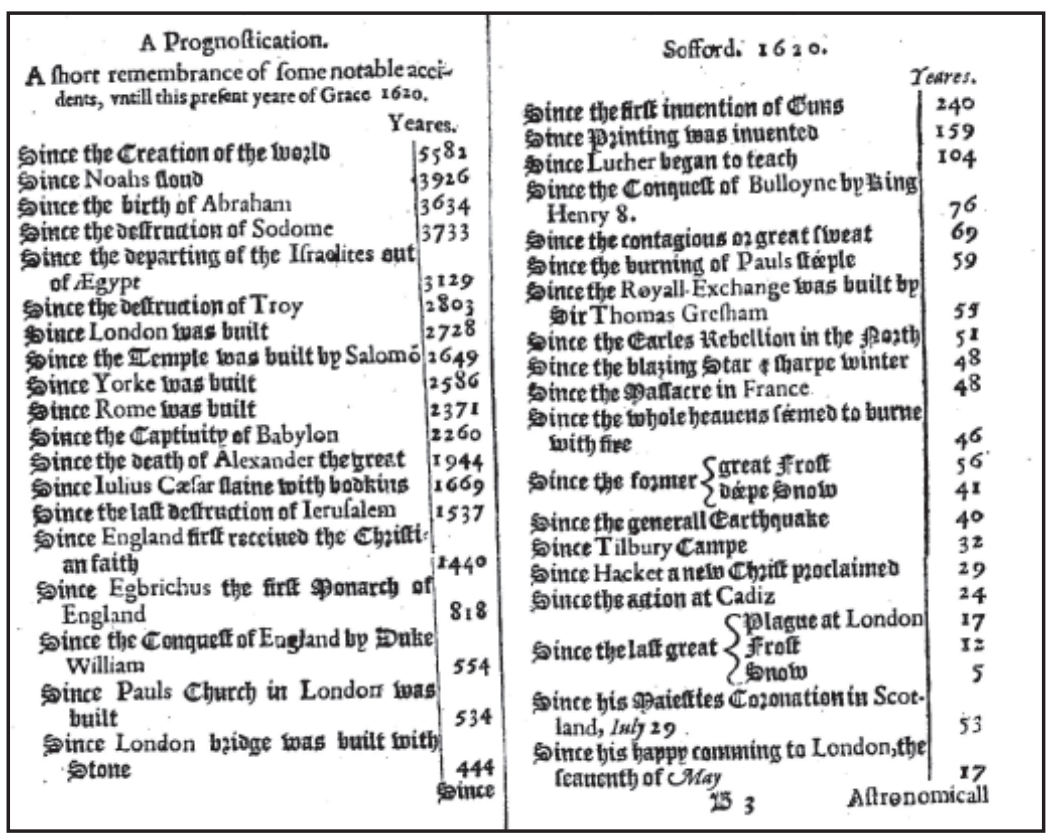

Illustration 1: Timeline from Sofford's Almanac for 1620. Sofford, Arthur. A new almanacke and prognostication for the yeare of our Lord God 1620, being bissextile or leapeyeare (London: printed for The Company of Stationers, 1620), pp. B2v-B3r. Lambeth Palace Library, by permission of Lambeth Palace Library. Reproduction of the image taken from Early English Books Online. Image published with permission of ProQuest. Further reproduction is prohibited without permission. 
in manuscript ones such as commonplace books, as Robert H. Ray's “The Herbert Allusion Book" demonstrates. ${ }^{113}$ Further, as Ian Green observes, Herbert's work appealed to readers across a wide range of political and religious identities, including both royalists and dissenters. ${ }^{114}$ Helen Wilcox makes a convincing case that seventeenth-century female readers found Herbert significant as well. ${ }^{115}$ In light of Herbert's wide readership, discussion of the link between theology and materiality may be not only a reflection of current critical interests, but also a doorway into a deep exploration of the experience of seventeenth-century readers.

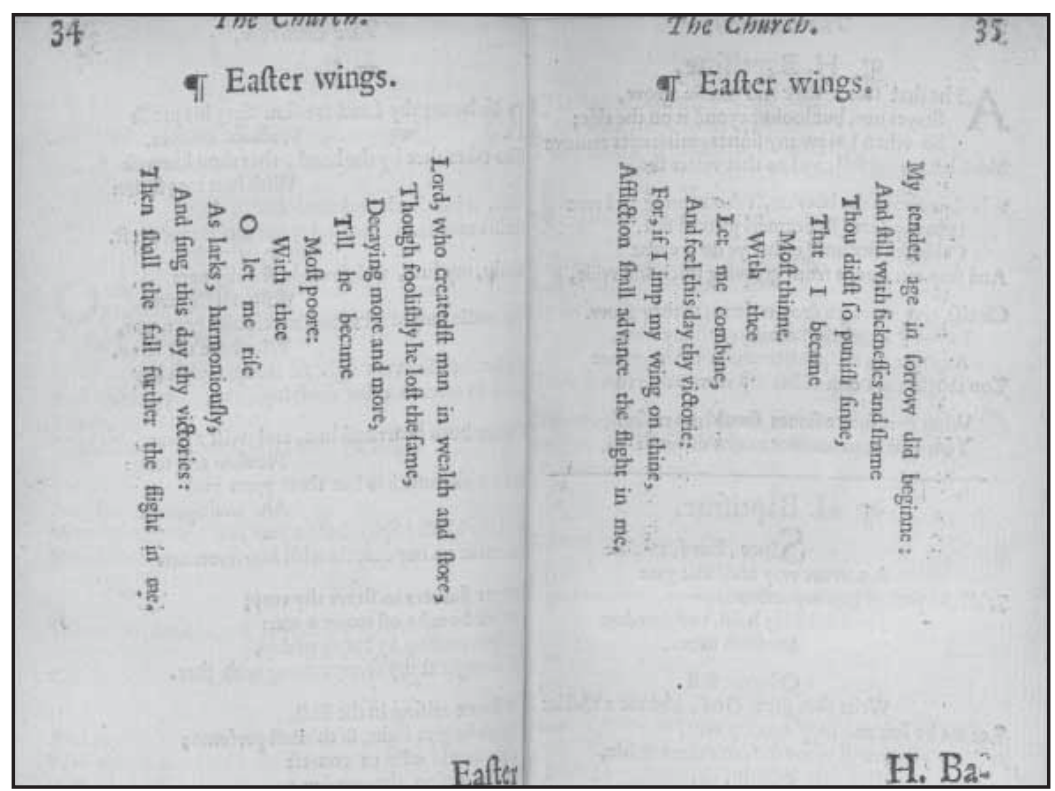

Illustration 2: "Easter Wings" in the 1633 first edition of The Temple. George Herbert, The Temple (Cambridge: printed by Thomas Buck and Roger Daniel, 1633), p. Bsv-B6r. By Permission of the Folger Shakespeare Library. 


\section{Notes}

1. I would like to thank my advisor Kristen Poole for her gracious and invaluable shaping work on this paper, and on my scholarly work in general; the Folger Shakespeare Library for its generous funding of my attendance at a colloquium entitled "Forms of Religious Experience in the $17^{\text {th }}$ Century British Atlantic World," led by David Hall and Laura Lunger Knoppers; Dr. Hall and Dr. Knoppers and the members of the seminar for their generous and helpful advice on revising the paper; and my colleague Joshua Calhoun for his patient and helpful readings of various drafts.

2. This paper will concentrate mostly on sources from the seventeenth century before 1640, but I have used terms such as "early modern" and "Renaissance readers" in order to avoid clumsy constructions.

3. Toliver, George Herbert's Christian Narrative (University Park, PA: The Pennsylvania State University Press, 1993).

4. Toliver, pp. 194, 207.

5. The poem beginning with the fall is the first one the reader reaches, turning each page from left to right, but since the poems in the 1633 edition are on adjacent pages oriented with the beginning of each line perpendicular to the title at the top of the page, McLeod suggests that the reader might have turned the book 90 degrees and read the one beginning with the individual life first. Randall McLeod, listed as Random Cloud, "FIAT fLUX," in Crisis in Editing: Texts of the English Renaissance, ed. Randall McLeod (New York: AMS, 1994), pp. 61-78, 32-35 included. See also George Herbert, The Temple (Cambridge: printed by Thomas Buck and Roger Daniel, 1633), sigs. B5v-B6r. The first edition is hereafter referred to in the notes as 1633 .

6. Toliver draws attention to this pattern (pp. 194, 207), as does Joseph Summers in George Herbert: His Religion and Art (Cambridge, MA: Harvard University Press, 1954; Binghamton, NY: Center for Medieval and Early Renaissance Studies, 1981), p. 144; citations are to the Center for Medieval and Early Renaissance Studies edition. Barbara Lewalski describes the poem as an emblem in which form and content work together, in Protestant Poetics and the Seventeenth-Century Religious Lyric (Princeton: Princeton University Press, 1979), p. 204.

7. Here I will focus on the material contexts of texts, but other historical and material contexts recently explored include: bodily experience, in Michael Schoenfeldt's Bodies and Selves in Early Modern England: Physiology and Inwardness in Spenser, Shakespeare, Herbert, and Milton (Cambridge: Cambridge University Press, 1999); Renaissance political customs, in Schoenfeldt's earlier volume, Prayer and Power: George Herbert and Renaissance Courtship (Chicago: University of Chicago Press, 1991); and Herbert's family relationships and their social and political contexts, in Jeffrey Powers-Beck's Writing the Flesh: The Herbert Family Dialogue (Pittsburgh, PA: Duqesne University Press, 1998).

8. See Lewalski, Protestant Poetics; Fish, The Living Temple: George Herbert and Catechizing (Berkeley: University of California Press, 1978); and Strier, Love Known: Theol- 
ogy and Experience in George Herbert's Poetry (Chicago: The University of Chicago Press, 1983).

9. Some more general works on the history of the book and the experience of early modern readers which I have found helpful in providing context for Herbert's work include Adrian Johns's The Nature of the Book: Print and Knowledge in the Making (Chicago: The University of Chicago Press, 1998); Jesse M. Lander's Inventing Polemic: Religion, Print, and Literary Culture in Early Modern England (Cambridge: Cambridge University Press, 2006); D. F. McKenzie's Bibliography and the Sociology of Texts (Cambridge: Cambridge University Press, 1999); and William Sherman's Used Books: Marking Readers in Renaissance England (Philadelphia: University of Pennyslvania Press, 2008).

10. Helen Wilcox, "A Note on the Text and Publication of Herbert's Poems," in The English Poems of George Herbert, ed. Helen Wilcox (Cambridge: Cambridge University Press, 2007), pp. xxxvii-xl. Further references to Herbert's poetry will be from this edition unless otherwise noted. Further citations give line numbers in the main body of this paper, and page numbers in the endnotes.

11. McLeod, writing as Cloud, "FIAT fLUX."

12. Kathleen Lynch, "Devotion Bound: A Social History of The Temple" in Books and Readers in Early Modern England, ed. Jennifer Andersen and Elizabeth Sauer (Philadelphia: University of Pennsylvania Press, 2002), pp. 177-97.

13. Ramie Targoff, Common Prayer: The Language of Public Devotion in Early Modern England (Chicago: The University of Chicago Press, 2001), Chapter 4.

14. D. F. McKenzie has also argued for the importance of a broad definition of text, including much more than written words, and certainly including oral speech. I limit my definitions here both for reasons of space and because much of Herbert's concern with texts does emphasize the relationship between words and the material on which they are written or inscribed in some way.

15. Oxford English Dictionary Online, s. v. “Text," <http://www.oed.com> (accessed July 14, 2008).

16. Paul Ricoeur, Time and Narrative, vol. 1, trans. Kathleen McLaughlin and David Pellauer (Chicago and London: The University of Chicago Press, 1984), p. 31.

17. This passage from section 8 of Aristotle's Poetics is relevant to Ricoeur's argument and the way I am using it:

Just as in the other imitative arts the single imitation is of a single thing, so also the story, since it is an imitation of action, ought to be of one action, and this a whole. And the parts of the events ought to have been put together so that when a part is transposed or removed, the whole becomes different and changes. For whatever makes no noticeable difference if it is added or not added is no proper part of the whole. (Aristotle, On Poetics, trans. Seth Benardete and Michael Davis [South Bend, Indiana: St. Augustine's Press, 2002], p. 26).

18. Ricoeur, vol. 1, p. 142. 
19. Ricoeur, Time and Narrative, vol. 2, trans. Kathleen McLaughlin and David Pellauer (Chicago and London: The University of Chicago Press, 1984), p. 23.

20. Ricoeur, vol. 1, pp. 150-152.

21. Alison Chapman, "Now and Then: Sequencing the Sacred in Two Protestant Calendars," Journal of Medieval and Early Modern Studies 33.1 (2003). I do not wish to overemphasize this difference. Renaissance Church of England uses of the calendar are in many ways indebted to medieval Catholic ones, and medieval Catholicism of course shared belief in the same basic faith events: creation, fall, redemption, and resurrection.

22. Chapman, pp. 101-114.

23. Hans Frei, The Eclipse of Biblical Narrative: A Study in Eighteenth and Nineteenth Century Hermeneutics (New Haven and London: Yale University Press, 1974), pp. 1-4.

24. Patrick Collinson, "The Coherence of the Text: How it Hangeth Together: The Bible in Reformation England," in The Bible, The Reformation and the Church: Essays in Honour of James Atkinson, ed. W. P. Stephens (Sheffield, England: Sheffield Academic Press, 1995), p. 92.

25. Collinson on pages 89 and 92 argues from the front matter for the Geneva Bible from 1602. My own description here is indebted to his but includes slightly different details. I have used The Bible. Translated according to the Ebrew and Greeke, and conferred with the best translations in diuers languages. With most profitable Annotations upon all the hard places, and other things of great importance, as may appeare in the Epistle to the Reader (London: printed by Christopher Barker, 1583). Early English Books Online, <http://eebo.chadwyck.com/home>. Early English Books Online is hereafter abbreviated as Еево.

26. The Bible, sig. Div.

27. The Bible, sigs. D2r-D2v.

28. Peter Stallybrass, "Books and Scrolls: Navigating the Bible," in Books and Readers in Early Modern England, ed. Jennifer Andersen and Elizabeth Sauer (Philadelphia: University of Pennsylvania Press, 2002).

29. George Herbert, George Herbert: The Complete English Works, ed. Ann Pasternak Slater, Everyman's Library 204 (New York: Alfred A. Knopf, 1995), p. 200.

30. Joyce Ransome, "Monotessaron: The Harmonies of Little Gidding," The Seventeenth Century 20.1 (2005), p. 22.

31. Paul Dyck, “'So rare a use': Scissors, Reading, and Devotion at Little Gidding," George Herbert Journal, 27.1-2 (2003 Fall-2004 Spring), pp. 67-81.

32. There was a continental tradition of producing harmonies, on which the English tradition was based. For more information, see Ransome, pp. 22-26 and Ian Green, Print and Protestantism in Early Modern England (Oxford: Oxford University Press, 2000), p. 136. Calvin's harmony of Matthew, Mark, and Luke, with commentary, was translated into English in 1584 and was reprinted in 1610, so it would have been available to English readers of the early seventeenth century (Green, p. 136). 
33. John Hiud, The Storie of Stories (London: printed by Miles Flesher, 1632), p. A3r. ЕЕВо.

34. Hiud, p. A8r.

35. Hiud, p. A6v.

36. Hiud, p. A7v.

37. Ransome suggests on pp. 24-25 that Little Gidding produced its own harmonies because English harmonies in print when Nicholas Ferrar had the idea of reading from them were intended for a scholarly audience and were not as suitable for the family use intended by Ferrar.

38. In addition to Ransome, Collinson, and Dyck, sources for information and commentary on the harmonies include chapter 3 of Stanley Stewart's George Herbert, which provides general descriptions and commentary (Boston: Twayne Publishers, A Division of G. K. Hall \& Co., 1986); C. Leslie Craig's "The Earliest Little Gidding Concordance," which offers a wide range of background information and describes the concordance now owned by the Harvard College Library (Harvard Library Bulletin, 1 [1947], pp. 311-31); Nancy Cabot's "The Illustrations of the First Little Gidding Concordance," Harvard Library Bulletin 3 (1949), pp. 139-42; and Materials for the Life of Nicholas Ferrar, ed. by Lynette Muir and John White (Leeds: The Leeds Philosophical and Literary Society Ltd, 1996).

39. Collinson, pp. 105-106.

40. Green, p. 136 .

41. Dyck, p. 74 .

42. Oxford English Dictionary Online, s. v. "Concordance," <http://www.oed.com> (accessed December 14, 2007).

43. Strangely enough, there seems to be little recognition in early modern response to the concordances of the irony implicit in literally cutting up a text in order to demonstrate its intellectual unity. Ransome states that not even Little Gidding's detractors raised objections to their cutting up of Bibles in order to make the concordances (p. 43, n. 26).

44. Quoted in Collinson, p. 106. This chart is also quoted elsewhere, notably in Craig, p. 324, but I have used Collinson's modernized spelling.

45. Quoted in Collinson, p. 106.

46. Ransome, pp. 23-24.

47. Muir and White, p. 76.

48. Muir and White, p. 19.

49. Bernard Capp, English Almanacs, 1500-1800: Astrology and the Popular Press (Ithaca, NY: 1979), p. 23.

50. Browne, Daniel. A new almanacke and prognostication for the yeare of our Lord God, 1620. Being bissextile or leape yeare. Composed and referred to the paralell and meridian of the citty of Chester, where the pole is mounted aboue the horizon 54. degrees, and may serue without sensible error, the west parts of Great-Britaine. Amplified with many neces- 
sary instructions, and profitable rules. (London: printed for The Company of Stationers, 1620), sigs. A2v-A3r. Еево.

51. William Dade, A new almanacke and prognostication with the forraigne computation, in which you may behold the state of this yeare of our Lord God 1620, being the leape-yeare (London: printed for The Company of Stationers, 1620), sig. A1v. Еeвo.

52. Gabriel Frende, A new almanacke and prognostication wherein you may behold the state of this present yeare of our Lord God, 1620, being bissextile or leape-yeare : calculated for the citty of London, and generally for all England (London: printed for The Company of Stationers, 1620), sig. A1v. Eebo.

53. Jeffery Neve, A new almanacke and prognostication, with the forraigne computation seruing for the yeare of our lord and sauiour Iesus Christ, 1620, being the bissextile or leape yeare: rectified for the eleuation of the pole articke and meridian of the famous towne of Great Yarmouth in Norfolke, and may serue generally for the most part of Great Brittaine (London: printed for The Company of Stationers, 1620), sig. A2r. EEBo.

54. Arthur Sofford, A new almanacke and prognostication for the yeare of our Lord God 1620, being bissextile or leape-yeare: calculated for the latitude and meridian of the most honorable citty of London, where the pole is exalted $51 \mathrm{grad}$. and $32 \mathrm{~min}$. and may very well serue for most parts of Great Brittaine (London: printed for The Company of Stationers, 1620), sigs. B2v-B3r. ЕЕВо.

55. John White, A new almanack and prognosticatio[n] for the yeare of our Lord God 1620, being the bissextile or leape yeare: calculated for the meridian of the most honorable citty of London, \& will serue generally for the monarchy of Great Brittaine (London: printed for The Company of Stationers, 1620), sig. B1v. EeBo.

56. John Woodhouse, An almanacke and prognostication for the yeare of our Lord God 1620, being the bissextile or leape yeare : containing sundry rules, notes and directions, very necessary for most sorts of men, seruing indifferently for all this kingdome of Great Brittaine, but more specially for the southerne partes (London: printed for The Company of Stationers 1620), sigs. A1v-A2r. Еево.

57. Sofford, 1620 , sigs. B2v-B3r.

58. Arthur Sofford, A new almanacke and prognostication for the yeere of our Lord God 1632, being bissextile or leape yeere : containing in it an ephemerides for the true place of the sunne in longitude of of the moon both in longitude and latitude: calculated especially for the latitude \& meridian of the most honourable city of London, but may very well serue for most parts of Great Britaine (London: printed for The Company of Stationers, 1632), sig. B2r. Еево.

59. Browne, sigs. A2v-A3r.

6o. Sofford, 1632, sigs. B2r-B4v.

61. While recognizing that Herbert's narrator is a persona who cannot be fully identified with Herbert himself, for the sake of stylistic variation I sometimes use Herbert's name to denote the narrator of a poem.

62. Collinson (pp. 104-105) and Dyck (pp. 70, 75-77) connect the interpretative strategies of the Little Gidding harmonies with Herbert's comments in poetry and/or 
prose, while Stewart devotes a whole chapter to the topic (pp.57-82). Collinson also connects the harmonies and Herbert's thought with the Geneva chart (pp. 104-105).

63. Wilcox, p. 210.

64. Wilcox, p. 211.

65. Thanks to Joshua Calhoun, who first pointed out to me how much agency the text possesses in this poem. Chana Bloch also stresses the productive tension in Herbert's belief that the text itself contains power, but that the reader's diligence helps to make that power apparent in the reader's life. See Bloch, Spelling the Word: George Herbert and the Bible (Berkeley: University of California Press, 1985), pp. 9-12. Kathleen Lynch points to the interaction between reader and text in the poem as "founded on an understanding of the variously layered and interrelated narratives of the bible as a unified field in which one tests the strength of one's own belief" (Lynch, p. 193).

66. Wilcox, p. 210.

67. Joan Thirsk states that herbal drinks taken for health reasons (potions) "obtruded more noticeably than before in the literature of the late sixteenth and the whole of the seventeenth century," in Food in Early Modern England: Phases, Fads, Fashions 1500-1760 (London: Hambledon Continuum, 2007), p. 307.

68. Wilcox, p. 210.

69. Wilcox, p. 210.

70. As Wilcox recognizes, criticism of this poem has often focused on delineating a theological position for its speaker (pp. 653-55). Gene Edward Veith, Jr. incorporates "Judgement" into a discussion of Herbert's investment in the Protestant doctrine of justification by faith, in Reformation Spirituality: The Religion of George Herbert (Lewisburg, PA: Bucknell University Press, 1985), pp. 75-76. Strier discusses it as an affirmation of the related Protestant investment in divine grace as opposed to human merit (Strier, pp. 2-4). Janis Lull reads it as a recognition that human works, including the poet's writing, cannot satisfy God, but God's own words can (in Lull, The Poem in Time: Reading George Herbert's Revisions of The Church [Newark: University of Delaware Press, 1990], pp.110-111). Michael Schoenfeldt reads the poem in relationship to others that discuss writing and contractual agreements between God and mortals, in Prayer and Power: George Herbert and Renaissance Courtship (Chicago: The University of Chicago Press, 1991), pp.187-9o. My argument centres on the links between expectations of theological coherence and attention to the literal pages of the New Testament in Herbert's metaphor, as well as on the historical context of metaphors of the heart as text.

71. Wilcox, pp. 176-8o.

72. Actually "Death" and "Dooms-day" are much more hopeful than their titles would indicate, but their titles still allow the thought of judgment to loom.

73. Eric Jager, The Book of the Heart (Chicago: University of Chicago Press, 2000), pp. 139-46. See Jager also for an extensive analysis of similar imagery, going back to classical and medieval precedents. 
74. Wilcox, p. 654 .

75. Wilcox, p. 654 .

76. Richard Carpenter, The conscionable Christian: or, The indeuour of Saint Paul, to haue and discharge a good conscience alwayes towards God, and men laid open and applyed in three sermons. Preached before the honourable judges of the circuit, at their seuerall assises, holden in Chard and Taunton, for the county of Somerset. 1620. (London: printed by Felix Kingston for John Bartlet, 1623), sig. H1r. Еево. Jager’s work (p. 140) first drew my attention to this book.

77. Wilcox, p. 654 .

78. Oxford English Dictionary Online, s. v. “Testament," <http://www.oed.com> (accessed December 14, 2007).

79. Oxford English Dictionary Online, s. v. "Testament" and "Covenant," <http://www. oed.com> (accessed December 14, 2007). Veith points out the dual function of the "Testament" in the poem as both record of Christ's actions and evidence of a covenant, but does not discuss the linguistic relationship documented by the Oxford English Dictionary (Veith, pp. $75^{-76}$ ). What interests me here is not only this dual function, but the ways in which it relies on the relationship between the narrative and material aspects of the text.

80. The sense of distance I am arguing for here functions much like that described by Anthony Kemp as an experience of the early church. Kemp argues that early Christian historians felt a sense of dislocation because their foundational story seemed to grow ever more distant as Christ and the apostles seemed to "recede each year further from the grasp of present knowledge, into the ungraspable tenuousness of collective memory." See Anthony Kemp, The Estrangement of the Past: A Study in the Origins of Modern Historical Consciousness (Oxford: Oxford University Press, 1991), p. 8.

81. "Affliction" is the only title to be used so often in The Temple, in spite of Herbert's fondness for poems linked by the same title.

82. Wilcox, p. 384. Wilcox suggests that the sources for the repeated word "come" are the collect for the last Sunday in Advent and the cry for Christ to come in Revelation 22:20 (Wilcox, p. 383). If readers heard these resonances, they would provide a link between the eschatological vision of the text of Revelation and the experience of time mediated through the communally experienced prayer book text.

83. See Robert H. Ray's compilation of allusions to Herbert in seventeenth-century sources, "The Herbert Allusion Book: Allusions to George Herbert in the Seventeenth Century," Studies in Philology 83.4 (1986), especially pp. 31, 77, 89, 113, 118, 153, and 159.

84. Wilcox, p. 384.

85. Wilcox, p. 385 .

86. Wilcox, p. 385 .

87. Wilcox, p. 386.

88. Wilcox, pp. 384-386.

89. Herbert, 1633, sig. E3r. 
90. Rosalie Colie, Paradoxia Epidemica: The Renaissance Tradition of Paradox (Princeton: Princeton University Press, 1966), pp. 200-201, 204.

91. Wilcox, p. 401.

92. Lewalski, p. 205. See fig. 12 in figures section following p. 210 for a reproduction of the image she discusses. Mary Cole Sloane also discusses Herbert's relationship to images of the heart in the emblem tradition in chapter 3 of The Visual in Metaphysical Poetry (Atlantic Highlands, N. J.: Humanities Press, 1981).

93. Wilcox, p. 401.

94. Martin Elsky offers an intriguing reading in the context of Renaissance handbooks emphasizing the relationship between the written and the spoken word, with the written word serving as a material thing revealing the essence of the thing named. He emphasizes the relationship between the material letters, read in different contexts to reveal meaning, and the essence of the name "Jesu" itself. See Elsky, "George Herbert's Pattern Poems and the Materiality of Language: A New Approach to Renaissance Hieroglyphics," English Literary History 50.2 (1983), pp. 245-260, esp. pp. 252253. My own focus here falls more on the relationship between the brokenness of the text and the ability to interpret further the whole.

95. Wilcox, p. 401.

96. Fish, pp. 30-35.

97. Fish, pp. 34-35.

98. Fish, p. 34

99. There is a debate about whether "Good Friday" should be read as one or two poems, since it appears as two separate poems in The Williams Manuscript, but as only one in the 1633 first printed edition. I have discussed it as one poem, since that is how the majority of early readers would have experienced it, but for the debate and a selection of commentators, see Wilcox, p. 125-29.

100. Ramie Targoff has argued that the experience of liturgy in the post-Reformation English church was actually more communally oriented toward one book than medieval Catholic practice had been. Medieval Catholics used related but separate books on the occasions when they brought books to Mass, while in Church of England services the officiant and the people were expected to attend to the same words in English at the same time (Targoff, pp. 14-22).

101. Wilcox, p. 125. Also see The Book of Common Prayer, (Cambridge: Printed by Thomas Buck and John Buck, 1630), sigs. B 7v-B8r.

102. Jager, pp. 108-111.

103. Barbara Harman, Costly Monuments: Representations of the Self in George Herbert's Poetry (Cambridge, MA: Harvard University Press, 1982), pp. 56-59.

104. Wilcox, p. 126.

105. Harman, p. 57.

106. Wilcox, p. 126.

107. Wilcox, p. 127. 
108. Jager, p. 111. Again, I wish to emphasize the links between early modern and medieval devotion as well as the differences between them. While Herbert's calendrical meditation is more focused on the life of Christ and less interested in the saints than medieval devotion, they have much in common in terms of textual metaphor.

109. Harman, p. 58.

110. Herbert, p. 37 .

111. Herbert, p. 37 .

112. Oxford English Dictionary Online, s. v. “Text," <http://www.oed.com> (accessed July 14, 2008).

113. Robert H. Ray, "The Herbert Allusion Book: Allusions to George Herbert in the Seventeenth Century," Studies in Philology 83.4 (1986).

114. Green, p. 392.

115. Helen Wilcox, "Women, Reading, and Devotion in Seventeenth-Century England" in Religion, Literature, and Politics in Post-Reformation England, 1540-1688, ed. Donna B. Hamilton and Richard Strier (Cambridge: Cambridge University Press, 1996), pp. 187-207. 